\title{
Evaluation of American and British rations for growing pigs
}

\author{
By R. S. BARBER, R. BRAUDE, ZENA D. HOSKING \\ AND K. G. MITCHELL \\ National Institute for Research in Dairying, Shinfield, Reading, England \\ AND W. H. BRUNER, V. R. CAHILL, J. J. GILLILAND, \\ R. F. GUNDLACH AND H. S. TEAGUE \\ Ohio Agricultural Research and Development Center, Wooster, Ohio, USA \\ (Received I6 August I965-Accepted I December 1965)
}

\begin{abstract}
1. A test was carried out simultaneously in Shinfield, Reading, England, and Columbus, Ohio, USA, using typical British and American rations for growing pigs. The rations were compounded in their country of origin; half of each consignment was used at the home station and the other half shipped to the overseas station. 2. Both restricted feeding and ad lib. feeding methods were used at each station. 3. A similar pattern of results was obtained at Shinfield and Columbus. Pigs receiving the American ration, which was higher in energy content, grew faster and required less feed per $\mathrm{kg}$ live-weight gain than pigs receiving the British ration. The higher energy content of the ration was probably responsible also for the poorer carcass quality of the pigs receiving the American ration, particularly the high fat content. The comparison between restricted feeding and $a d$ lib. feeding was not affected by the type of ration. Restricted feeding resulted in slower growth rate, slightly better efficiency of feed conversion and considerably better carcass quality.
\end{abstract}

In the United States, typical rations for growing pigs are based on maize and soya-bean meal, whereas in Great Britain they most commonly contain barley, wheat by-product and white fish meal. A controversy exists about the relative nutritional merits of these rations, often obscured by differences in the quality of the ingredients used in comparative trials carried out independently in each country.

The purpose of the test to be described was to see if nutritionally adequate rations in normal use in each country would give satisfactory, and similar, results on both sides of the Atlantic. Arrangements were made to ship complete mixed rations from one country to the other. By doing this, rather than merely exchanging formulas, we made certain that differences in the quality of locally available ingredients were not a factor causing difficulty in the interpretation of results. It was recognized that the two types of ration contained different amounts of many nutrients and there was no attempt to make them supply equal amounts.

In the United States pigs are commonly fed $a d$ lib., whereas in Great Britain restricted feeding is usually practised with growing pigs intended for bacon. In comparing the American and British types of ration both methods of feeding were used at each centre.

\section{EXPERIMENTAL}

Animals. At Shinfield, home-bred Large White pigs were used; in the State Evaluation Station at Columbus, Yorkshire pigs, the breed most similar to Large Whites, were purchased for the experiment from two local breeders. At the beginning of the test the pigs were 8-ro weeks old and their live weights ranged from $\mathrm{I}_{4}$ to $22 \mathrm{~kg}$. 
Experimental design. General information on the design of the test, the number of pigs used and their live weight is given in Table r. Two tests were carried out at each centre.

Table I. Numbers, sex and mean weights of the pigs

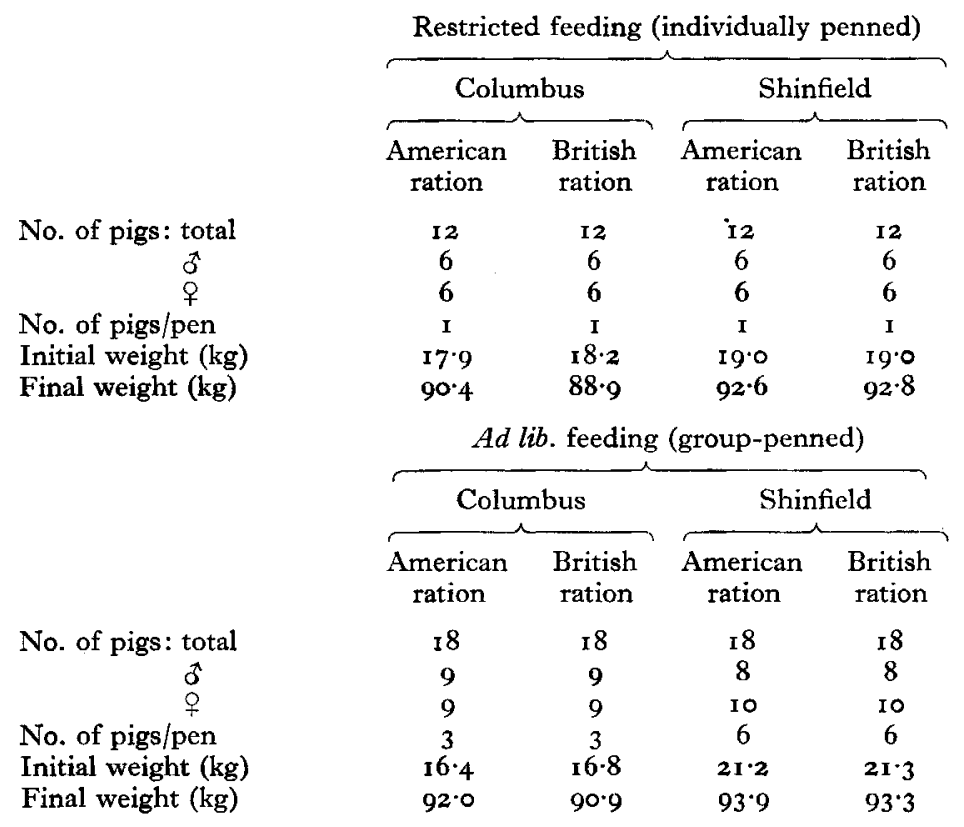

(1) Restricted feeding with individual penning and feeding: At each centre twelve pairs of pigs were used, a pair of litter-mates forming a random block in the experiment at Shinfield and a pair of sire-mates in the trial at Columbus. At both centres an overall balance for sex and initial weight within treatments was attempted. Feed was allocated according to live weight using a scale as described later.

(2) Ad lib. feeding with group penning and feeding: A randomized block design was used at each centre. At Shinfield there were three blocks of two pens, each containing six pigs receiving the same ration. Litter origin, initial weight and sex were taken into consideration when allocating pigs to each block. At Columbus, six blocks of two pens each containing three pigs were used, with blocking according to live weight; pigs were subsequently allocated to pens within blocks so that over the whole experiment equal numbers of barrows and gilts from each sire received each treatment.

Differences in the blocking systems and pen sizes at the two centres arose from restrictions imposed by the accommodation available for the experimental pigs. Feeding was ad lib.

Rations. The ration chosen at Columbus was similar in composition to that used for pigs at the State Evaluation Station; the Shinfield ration was that now in use there as the control ration in nutritional experiments. The two rations were fairly typical of those generally used in the USA and Great Britain. 
Each ration consisted of a no. I mixture given from the beginning of the experiment until the pigs reached $54^{\circ} 4 \mathrm{~kg}$ live weight, and a no. 2 mixture given from then until slaughter; the ingredients are shown in Table 2. Mean values for chemical composition are given in Table 3, chemical analyses at Columbus and Shinfield having given similar results. All rations were in pelleted form, the size of the pellets being $\frac{3}{16}$ in.

Table 2. Percentage composition of the rations.

Ingredient

American

Ground shelled maize
Meat and bone scraps ( $50 \%$ crude prote
Soya-bean oil meal ( $50 \%$ crude protein)
Dehydrated lucerne meal ( $7 \%$ crude prot
Mineral mixture†
Trace-mineralized salt
Antibiotic-vitamin-arsenical-antioxidant
Pellet binder\$
Barley meal
Weatings $\|$
White fish meal ( $66 \%$ crude protein)
Vitamins A and D supplement $\uparrow$
Limestone flour
Salt
Molasses
Copper sulphate and zinc carbonate**

\section{Ration Ration \\ no. $I^{*}$ no. 2 *}

$\begin{array}{rr}76.5 & 80.4 \\ 3.0 & 2.0 \\ 14.0 & 11.0 \\ 2.5 & 2.5 \\ 1.0 & 1.1 \\ 0.5 & 0.5 \\ 0.5 & 0.5 \\ 2.0 & 2.0\end{array}$

$\begin{array}{cc}51.0 & 54.0 \\ 36.0 & 36.0 \\ 7.0 & 3.0 \\ + & + \\ 1.0 & 1.5 \\ - & 0.5 \\ 5.0 & 5.0 \\ + & +\end{array}$

* Ration no. I given up to $54.4 \mathrm{~kg}$ live weight and no. 2 thereafter to slaughter.

$\uparrow$ Dicalcium phosphate with zinc carbonate added to supply $80 \mathrm{ppm}$ in the complete ration.

¥ Contains per ton: $10 \mathrm{~g}$ chlortetracycline, $7.5 \mathrm{~g}$ zinc bacitracin and $2.5 \mathrm{~g}$ procaine penicillin, $2.5 \mathrm{~g}$ riboflavine, ro $\mathrm{g}$ calcium pantothenate, $16 \mathrm{~g}$ nicotinic acid, $18 \mathrm{mg}$ vitamin $\mathrm{B}_{12}$ and 180000 i.u. vitamin $\mathrm{D}_{2}, 90 \mathrm{~g}$ arsanilic acid, and $0^{\circ} 25 \mathrm{lb}$ butylated hydroxytoluene as an antioxidant.

$\S$ Dura Bond; Cargill Inc., 200 Grain Exchange, Minneapolis I5, Minnesota, USA.

\| Fine miller's offal from the production of wheat flour, containing from 14 to $16 \%$ crude protein and not more than $6 \%$ crude fibre.

T To supply 4500 i.u. vitamin $A$ and 1125 i.u. vitamin $D_{3} / \mathrm{kg}$ in ration no. $I$ and half these quantities in ration no. 2 .

** To supply $0.1 \%$ copper sulphate and $0.02 \%$ zinc carbonate.

\section{Table 3. Chemical composition of the rations}

\begin{tabular}{|c|c|c|c|c|c|}
\hline \multirow{2}{*}{ Ration } & \multirow{2}{*}{$\begin{array}{c}\text { Dry matter } \\
(\%)\end{array}$} & $\begin{array}{l}\text { Crude } \\
\text { protein }\end{array}$ & $\begin{array}{l}\text { Ether } \\
\text { extract }\end{array}$ & $\begin{array}{l}\text { Crude } \\
\text { fibre }\end{array}$ & Ash \\
\hline & & \multicolumn{4}{|c|}{ (as $\%$ of dry matter) } \\
\hline American no. I & $87 \cdot 8$ & $18 \cdot 9$ & $3 \cdot 2$ & $3 \cdot 4$ & $5 \cdot 4$ \\
\hline American no. 2 & $88 \cdot 4$ & $16 \cdot 8$ & $3 \cdot 7$ & $3 \cdot 8$ & $5 \cdot 3$ \\
\hline British no. I & $87 \cdot 6$ & $18 \cdot 4$ & $\mathrm{I} \cdot 8$ & $5 \cdot 0$ & $6 \cdot 0$ \\
\hline British no. 2 & $88 \cdot 4$ & 14.5 & $2 \cdot 3$ & $5 \cdot I$ & $6 \cdot 2$ \\
\hline
\end{tabular}

The Columbus ration was manufactured by Central Soya, McMillen Feed Division, Decatur, Indiana, USA, and the Shinfield ration was manufactured by the British Oil and Cake Mills Ltd, Hull, England. The shipment of the rations from the manufacturers to the experimental centres was arranged and paid for by the Soybean 
Council of America. We wish to acknowledge the very helpful co-operation of these organizations.

Experimental routine. The no. I mixtures were introduced gradually over a 3 -day period. The changeover from mixture no. I to mixture no. 2 was made abruptly when, at the weekly weighing, the weight of the individual pigs in test $\mathrm{I}$ or the mean weight of pigs in a group in test 2 exceeded $52.5 \mathrm{~kg}$. The mixtures were given dry, and water was freely available to all the pigs.

The pigs were weighed on the same day and at about the same time each week. After each weighing the feed allowance of the pigs on restricted feeding was adjusted according to a scale which allowed $0.907 \mathrm{~kg}(2 \cdot 0 \mathrm{lb})$ feed daily for pigs weighing I6.3 $\mathrm{kg}\left(3^{6} \mathrm{lb}\right)$ with an increase of $0.045 \mathrm{~kg}(0 \cdot \mathrm{llb})$ daily for every $\mathrm{I} \cdot 3^{6} \mathrm{~kg}\left(3^{\circ} \circ \mathrm{lb}\right)$ increase in body-weight to a maximum of $2.95 \mathrm{~kg}(6.5 \mathrm{lb})$ feed at a weight of $76.7 \mathrm{~kg}$ $(\mathrm{r} 69.0 \mathrm{lb})$. This maximum level of feed was then maintained until the pigs reached slaughter weight. The pigs were fed twice daily. The feed consumption of the groups fed ad lib. was determined weekly.

All pigs exceeding $90 \mathrm{~kg}$ live weight at the weekly weighing were dispatched to the factory and slaughtered on the same day.

Assessment of carcass quality. It was not possible to follow identical methods of assessment at both centres. The method described in detail by Buck, Harrington \& Johnson (1962) was used at Shinfield, whereas at Columbus the method normally adopted at the Ohio Evaluation Centre was used. It was agreed, however, that eight identical measurements should be taken at both centres.

Statistical analysis. The results from each centre for the pigs on restricted feeding were analysed separately by standard methods. For those observations common to both centres, the analyses were then combined and the centre differences tested against the variability between blocks within centres ( 22 degrees of freedom); the interaction of centre with treatment was not significant at the $5 \%$ level for any of the observations studied. Treatment, or ration, differences were tested against the interaction of blocks and treatments within centres ( 22 degrees of freedom for those observations made at both centres and I I degrees of freedom for those at only one centre).

A similar pattern of analyses was adopted for the results from the pigs fed ad lib. Comparisons of centres and treatments were again made on a between-block and a within-block basis respectively, and the corresponding degrees of freedom are those noted for the standard errors shown in Tables 5,6 and 7 .

The effect of sex was briefly examined in some ancillary analyses and, as might be expected, was important for some of the measurements, particularly those of carcass fat, but treatment mean values were not adjusted for the effect of sex because barrow and gilt representation within rations (Table $\mathrm{I}$ ) ensured that treatment comparisons were very little affected. When sex appeared to have an important bearing on the results, this is commented upon in the text. 


\section{RESULTS}

Mean values for the observations common to the individually penned pigs on restricted feeding given either the American type (Am) or British type (Br) rations at both Columbus (Co) and Shinfield (Sh) are shown in Table 4, and those for the group-penned pigs fed ad lib. in Table 5. Mean values obtained for the pigs on restricted and $a d$ lib. feeding were, of course, not identical, but ration effects and differences between centres were, with two exceptions, virtually the same under both experimental regimes. The general comments which follow apply, therefore, to pigs on both restricted and $a d l i b$. feeding unless specific distinction is made.

Table 4. Mean values for the performance of individually penned pigs on restricted feeding and the mean differences between rations and between centres, twelve pigs receiving each ration at each centre

No. of days on test

Daily weight gain $(\mathrm{kg})$

Efficiency of feed conversion $(\mathrm{kg} / \mathrm{kg})$

Carcass length $(\mathrm{mm})$

Fat depth (mm): shoulder mid-back loin:

Eye muscle $(\mathrm{mm}): \downarrow$ minimum measurement $A$ measurement $\mathrm{B}$

\begin{tabular}{|c|c|c|c|}
\hline \multicolumn{2}{|c|}{$\begin{array}{l}\text { Columbus } \\
\text { (Co) }\end{array}$} & \multicolumn{2}{|c|}{$\begin{array}{l}\text { Shinfield } \\
\text { (Sh) }\end{array}$} \\
\hline $\begin{array}{l}\text { Ameri- } \\
\text { can } \\
\text { ration } \\
(\mathrm{Am})\end{array}$ & $\begin{array}{l}\text { Brit- } \\
\text { ish } \\
\text { ration } \\
(\mathrm{Br})\end{array}$ & $\begin{array}{c}\text { Ameri- } \\
\text { can } \\
\text { ration } \\
(\text { Am) }\end{array}$ & $\begin{array}{l}\text { Brit- } \\
\text { ish } \\
\text { ration } \\
(\mathrm{Br})\end{array}$ \\
\hline $\begin{array}{r}\text { II2-2 } \\
0.65 \\
2 \cdot 86\end{array}$ & $\begin{array}{r}123.8 \\
0.5^{8} \\
3.3^{8}\end{array}$ & $\begin{array}{r}104 \cdot 2 \\
0 \cdot 7 x \\
3 \cdot 75\end{array}$ & $\begin{array}{r}1 \times 9.9 \\
0.62 \\
3.21\end{array}$ \\
\hline $\begin{array}{l}75 \mathrm{I} \\
46 \cdot \mathrm{I}\end{array}$ & $\begin{array}{c}745 \\
44.9\end{array}$ & $\begin{array}{c}765 \\
54 \cdot 7\end{array}$ & $\begin{array}{l}779 \\
5 I^{1} \cdot 5\end{array}$ \\
\hline $25 \cdot 8$ & 23.9 & $31 \cdot 0$ & 29.5 \\
\hline $29^{\circ} 4$ & $26 \cdot 9$ & $3^{6 \cdot 9}$ & $33^{\circ} 0$ \\
\hline $37 \cdot 0$ & $34 \cdot 7$ & $42 \cdot 2$ & $37 \cdot 0$ \\
\hline $8 I \cdot 2$ & 83.4 & $75 \cdot 8$ & $77^{\circ} 9$ \\
\hline $47 \cdot \mathrm{I}$ & $46 \cdot 2$ & $49 \cdot 2$ & $47^{\circ} \cdot 6$ \\
\hline
\end{tabular}

Mean difference Mean difference between rations $\uparrow$ between centres $\uparrow$ $(\mathrm{Am}-\mathrm{Br})$ (Co-Sh)

$0.08 \pm 0.013 * *$
$-0.49 \pm 0.068 * *$

$-0.05 \pm 0.015^{* *}$ $0.14 \pm 0.072^{\text {ns }}$

$-4 \cdot 0 \pm 4 \cdot 9^{\mathrm{ns}}$

$2 \cdot 2 \pm r \cdot 4^{\text {ns }}$

$r \cdot 7 \pm 1 \cdot 10^{\text {ns }}$

$-24 \cdot 0 \pm 6 \cdot I^{* * *}$ $-7 \cdot 6 \pm 1 \cdot 56 * *$

$-5 \cdot 4 \pm 1 \cdot 51 * *$

$3 \cdot 2 \pm 0.85 * *$

$-6 \cdot 8 \pm I \cdot 79^{* * *}$ $3.8 \pm 1.09^{* *} \quad-3.8 \pm 1.89^{\mathrm{ns}}$

$-2 \cdot 2 \pm 1 \cdot 20^{n s}$

$1 \cdot 2 \pm r \cdot 00^{\text {ns }}$

$5 \cdot 4 \pm I \cdot 62 * *$

$-r \cdot 8 \pm r \cdot 48^{n s}$

ns, $P>0.05 . \quad * * \quad P<0.01$.

$\dagger$ All standard errors with 22 df.

$\ddagger \mathrm{A}$, the greatest width of the muscle cross-section; B, the greatest depth of the muscle cross-section at right angles to $A$.

Live-weight gain and efficiency of feed conversion. The pigs receiving ration Am grew faster and utilized their feed more efficiently than those given ration $\mathrm{Br}$. The average daily gain in weight at Co was less than at Sh but the efficiency of feed conversion tended to be similar at both centres. The mean daily live-weight gain of pigs at Co given ration $\mathrm{Am}$ was no better than of pigs at $\mathrm{Sh}$ given ration $\mathrm{Br}$ (the difference was only $0.03 \pm 0.019 \mathrm{~kg} /$ day for pigs on restricted feeding and $0.01 \pm 0.030 \mathrm{~kg} /$ day for pigs on ad lib. feeding), but the efficiency of feed conversion of the pigs at Co was much superior to that of the pigs at $\mathrm{Sh}$ (the differences were $0.35 \pm 0.096$ and $0.43 \pm$ $0.021 \mathrm{~kg}$ ration $/ \mathrm{kg}$ live-weight gain for pigs on restricted and $a d \mathrm{lib}$. feeding respectively).

Carcass length. There was a tendency for the pigs at Sh on ration Am to be shorter than those on ration $\mathrm{Br}$; but, taken over both centres, ration did not affect significantly 
the lengths of the pigs. The carcasses of the pigs at Sh, however, were much longer than those at Co.

For the pigs on restricted feeding, carcasses of gilts were on average nearly $9 \mathrm{~mm}$ longer than those of barrows, but this difference was not significant. For the pigs on ad lib. feeding, however, carcasses of gilts were on average $12 \mathrm{~mm}$ longer $(P<0.05)$ at $\mathrm{Co}$ and $\mathrm{I} 8 \mathrm{~mm}$ longer $(P<0.0 \mathrm{I})$ at $\mathrm{Sh}$ than those of barrows.

Table 5. Mean values for the performance of group-penned pigs on ad lib. feeding and the mean differences between rations and between centres, eighteen pigs receiving each ration at each centre

No. of days on test

Daily weight gain $(\mathrm{kg})$

Efficiency of feed conversion $(\mathrm{kg} / \mathrm{kg})$

Carcass length ( $\mathrm{mm}$ )

Fat depth (mm): shoulder mid-back loin:

Eye muscle $(\mathrm{mm}): \S$ minimum
maximum measurement A measurement $B$

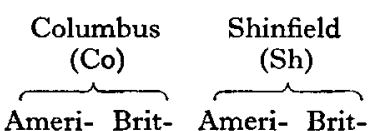

\begin{tabular}{|c|c|c|c|c|c|}
\hline $\begin{array}{l}\text { Amer1- } \\
\text { can } \\
\text { ration } \\
(\mathrm{Am})\end{array}$ & $\begin{array}{l}\text { Brit- } \\
\text { ish } \\
\text { ration } \\
(\mathrm{Br})\end{array}$ & $\begin{array}{l}\text { Ameri- } \\
\text { can } \\
\text { ration } \\
\text { (Am) }\end{array}$ & $\begin{array}{l}\text { Brit- } \\
\text { ish } \\
\text { ration } \\
(\mathrm{Br})\end{array}$ & $\begin{array}{c}\text { Mean difference } \\
\text { between rations } \dagger \\
(\mathrm{Am}-\mathrm{Br})\end{array}$ & $\begin{array}{c}\text { Mean difference } \\
\text { between centres } \ddagger \\
\text { (Co-Sh) }\end{array}$ \\
\hline
\end{tabular}

$\begin{array}{llll}97.9 & 103.1 & 86.1 & 92.4\end{array}$

$\begin{array}{llllll}0.78 & 0.73 & 0.85 & 0.79 & 0.06 \pm 0.021 * * & -0.07 \pm 0.023^{*}\end{array}$

$2.92 \quad 3.21 \quad 2.91 \quad 3.35-0.36 \pm 0.015^{* *}-0.06 \pm 0.036^{\mathrm{ns}}$

$\begin{array}{llllll}754 & 756 & 775 & 784 & -6.0 \pm 4 \cdot 4^{\text {ns }} & -24 \cdot 0 \pm 4 \cdot 7^{* *}\end{array}$

$\begin{array}{llllll}47.0 & 44.7 & 60.4 & 56.2 & 3.2 \pm \mathrm{I} \cdot 2 \mathrm{I} * * & -12.4 \pm 2.0 \mathrm{~T} *\end{array}$

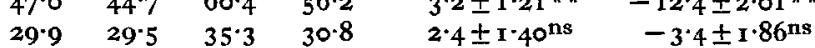

$34.3 \quad 30 \cdot 1 \quad 4 I \cdot 3 \quad 34 \cdot 7 \quad 5 \cdot 4 \pm I \cdot 20^{*} * \quad-5 \cdot 8 \pm I \cdot 7 I^{*}$

$\begin{array}{llllll}42 \cdot 3 & 39.1 & 44.7 & 38.8 & 4 \cdot 6 \pm 1 \cdot 23^{* *} & -1 \cdot 0 \pm 1 \cdot 5^{8 \mathrm{~ns}}\end{array}$

$\begin{array}{llllll}79.9 & 80.4 & 74.2 & 74.2 & -0.2 \pm 1 \cdot I^{\mathrm{ns}} & 6.0 \pm 0.94^{*} *\end{array}$

$47 \cdot 2 \quad 48 \cdot 3 \quad 47^{\circ} \cdot \quad 47^{\cdot 1} \quad-0.6 \pm 0.97^{\text {ns }} \quad 0.7 \pm 1 \cdot 3^{8 \mathrm{~ns}}$

ns, $P>0.05 . * 0.05>P>0.01 . * * * 0<01$.

$\dagger$ All standard errors with 6I df except for efficiency of feed coversion with $7 \mathrm{df}$.

$\ddagger$ All standard errors with $7 \mathrm{df}$.

$\S$ See second footnote, Table 4 .

Shoulder and mid-back fat thickness. The fat at the shoulder and at the mid-back was thicker for pigs on ration $\mathrm{Am}$ than for those on ration $\mathrm{Br}$, but was significantly so only at the shoulder of the pigs on ad lib. feeding. At these two points the fat was less thick in pigs at Co than in those at Sh, significantly so except at the mid-back position of the pigs on ad lib. feeding.

At both shoulder and mid-back, barrows were fatter, on average, than gilts given the same rations at the same centre. Differences in the thickness of fat of barrows and gilts on restricted feeding were about 4 and $5 \mathrm{~mm}$ at the two points, whereas in the pigs on $a d l i b$. feeding the only marked difference $(6 \mathrm{~mm})$ was for shoulder fat in those at $\mathrm{Sh}$.

Loin-fat thickness. Loin fat, both minimum and maximum, was significantly thicker for pigs on ration Am than for those on ration Br. Minimum loin-fat values were considerably greater for pigs at $\mathrm{Sh}$ than for those at Co but differences between centres for maximum loin-fat thickness were much smaller.

For both minimum and maximum measurements barrows on restricted feeding were, on average, slightly fatter than gilts (about $\mathrm{I} \mathrm{mm}$ ) given the same ration, except 
for those in Sh given ration Am which were significantly fatter (about $8 \mathrm{~mm}$ ). Among the pigs on ad lib. feeding, the barrows were always significantly fatter than the gilts, the mean differences being about $4 \mathrm{~mm}$ at Co and $7 \mathrm{~mm}$ at Sh. Loin-fat thickness was invariably greatest in barrows on ration $\mathrm{Am}$ and least in gilts on ration $\mathrm{Br}$, and the mean differences, for both maximum and minimum measurements, approximated to 4 and II $\mathrm{mm}$ in the pigs on restricted feeding, and to 8 and $\mathrm{I} 4 \mathrm{~mm}$ in the pigs on ad lib. feeding, at Co and Sh respectively. Fat measurements obtained for gilts on ration $\mathrm{Am}$ were very similar to those for barrows on ration $\mathrm{Br}$ in each instance.

Eye muscle measurements ( $A$ and $B$ ). Except that pigs on restricted feeding on ration Am tended to have slightly smaller $\mathrm{A}$ measurements than those on ration $\mathrm{Br}$, eye muscle measurements were very similar for pigs on both rations; A, B, C, K and J measurements made according to Buck et al. (1962) are briefly defined in Tables 4 and 6. Eye muscle $A$ measurements were notably higher for the pigs at $\mathrm{Co}$, but the $B$ values were much the same at the two centres.

In pigs on ad lib. feeding only, measurements $\mathrm{A}$ and $\mathrm{B}$ were significantly greater for the gilts than for the barrows; the difference was about $5 \mathrm{~mm}$.

\section{Observations made only on the pigs at Shinfield}

Mean values for the measurements taken only on the pigs at Shinfield given either the American-type or British-type rations are shown in Table 6.

Shoulder depth. Shoulder depth measurements were very similar for pigs on the two rations.

Fat over eye muscle $(C)$. The $\mathrm{C}$ measurements were much larger for the pigs on ration $\mathrm{Am}$ than on ration $\mathrm{Br}$. The $\mathrm{C}$ measurements for barrows were significantly greater than for gilts, differences between the sexes averaging $5 \mathrm{~mm}$ for the pigs on restricted feeding and $8 \mathrm{~mm}$ for the pigs on ad lib. feeding.

Table 6. Mean values for the observations made only on the pigs at Shinfield, twelve pigs receiving each ration on restricted feeding and eighteen pigs on ad. lib feeding

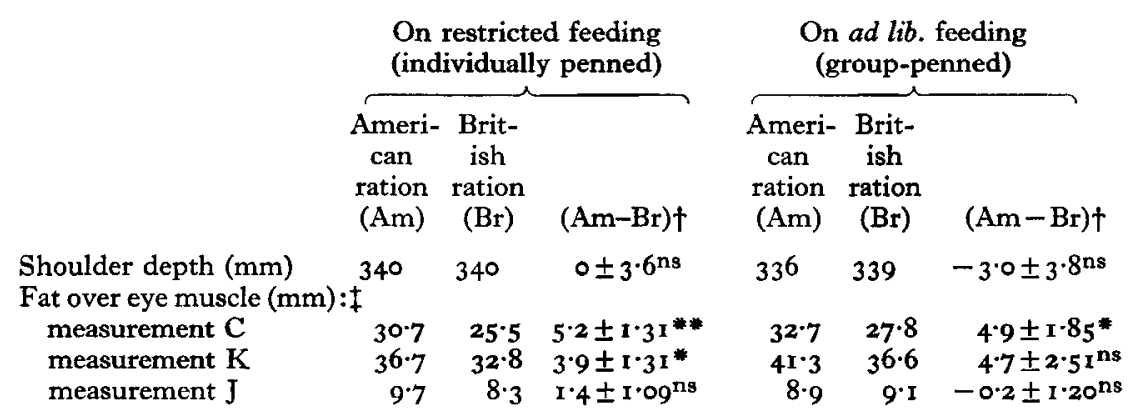

ns, $P>0.05$. *0.05 $>P>0.01 . \quad * * P<0.01$.

$\dagger$ Difference between ration mean values and its standard error with $I I$ df for pigs on restricted feeding and $30 \mathrm{df}$ for pigs on ad lib. feeding.

$\ddagger \mathrm{C}$, the depth of subcutaneous fat plus skin immediately over B (see Table 4 ); $\mathrm{K}$, the depth of subcutaneous fat plus skin over the dorsolateral corner of the muscle cross-section; $J$, the greatest depth of the third layer of subcutaneous fat. 
Fat over eye muscle $(K)$. The $\mathrm{K}$ values were greater for pigs on ration $\mathrm{Am}$ than on ration $\mathrm{Br}$. The $\mathrm{K}$ measurements for barrows were significantly larger than those for gilts, and the differences, irrespective of ration, were about $7 \mathrm{~mm}$ for the pigs on restricted feeding and I $\mathrm{mm}$ for the pigs on ad lib. feeding.

Fat over eye muscle $(\mathfrak{f})$. These measurements were not significantly affected by ration.

\section{Observations made only on the pigs at Columbus}

Mean values for carcass measurements made only on the pigs at Columbus given either the American-type or British-type rations are shown in Table 7.

Chilled carcass weight. The chilled carcass weight of pigs given ration Am was significantly higher than of those receiving ration $\mathrm{Br}$. Restricted feeding, compared with ad lib. feeding, resulted in a lower chilled carcass weight on both rations.

Table 7. Mean values for the observations on weights of carcass and wholesale cuts made only on the pigs at Columbus, twelve pigs receiving each ration on restricted feeding and eighteen pigs on ad lib. feeding

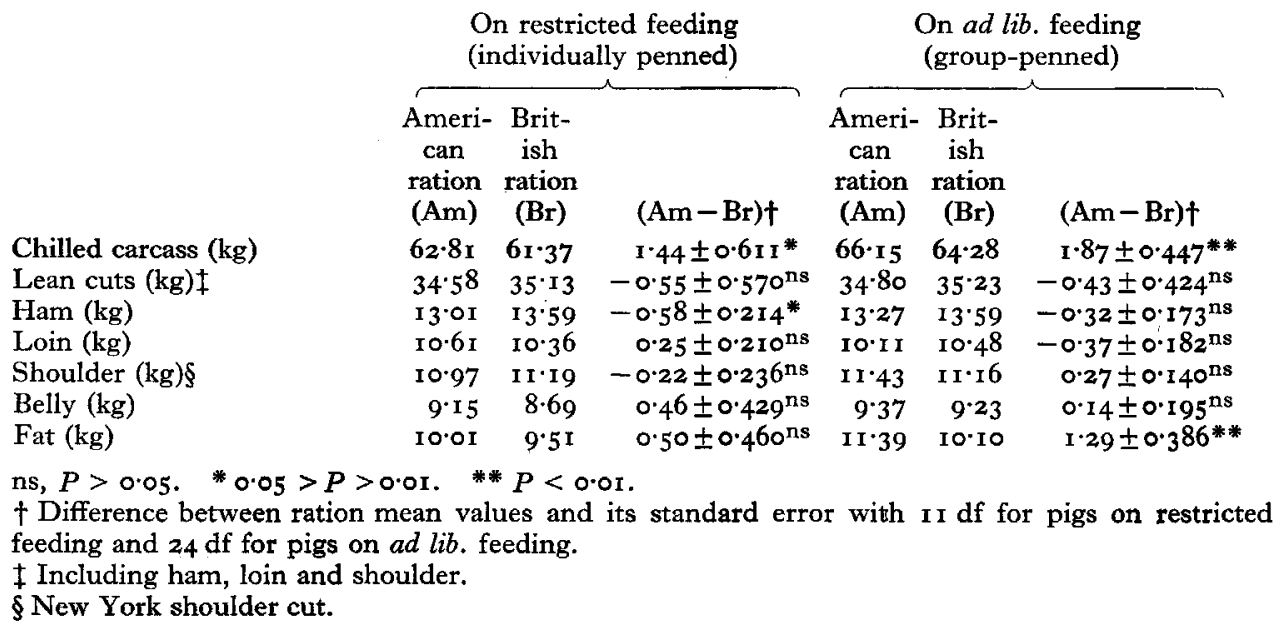

Individual wholesale cuts. The carcasses were cut in joints according to a commercial routine used in Ohio. The weight of ham from pigs given ration $\mathrm{Br}$ was significantly greater than from pigs on ration Am for the pigs on restricted feeding, but not for the pigs on ad lib. feeding. No other wholesale cut weights differed significantly between the two rations with either feeding regime.

Lean cuts and fat. The weight of lean cuts in the carcass was very similar for pigs on the two rations. The pigs on ad lib. feeding produced significantly more fat when given ration $\mathrm{Am}$ than when given ration $\operatorname{Br}(P<0.01)$. The trend was in the same direction for the pigs on restricted feeding but the difference was not significant. On both rations $a d$ lib. feeding produced more fat than restricted feeding.

Chemical composition of the longissimus dorsi. The $\mathrm{pH}$, and content of moisture, fat, protein and ash were determined in the longissimus dorsi near the tenth rib. The $\mathrm{pH}$ values in pigs on ad lib. feeding were significantly higher than in pigs on restricted 
feeding, irrespective of ration. Although the difference was not significant, $\mathrm{pH}$ values in pigs given ration $\mathrm{Br}$ were higher than those given ration $\mathrm{Am}$.

Pigs on ration $\mathrm{Br}$ had significantly less total fat in this muscle than pigs on ration Am.

The total moisture content of the longissimus dorsi in pigs on ad lib. feeding receiving ration $\mathrm{Am}$ was lower than in the corresponding pigs given ration $\mathrm{Br}$. Protein content in the pigs on restricted feeding given ration $\mathrm{Br}$ was higher than in the other three groups. The pigs on $a d \mathrm{lib}$. feeding receiving ration $\mathrm{Br}$ had a significantly lower ash content than pigs given ration Am.

Subjective firmness and structure. There was a general trend for pigs on ad lib. feeding to be firmer at the longissimus dorsi and at the ham area. Structure was not significantly affected by treatments.

Subjective evaluation of marbling. No significant difference due either to ration or to method of feeding was observed for the average marbling score of the gluteus medius and gluteus profundus muscles. Marbling scores for the longissimus dorsi muscle were higher for pigs given ration Am.

Colour evaluation. Muscle colour was evaluated by a panel and also by a measurement of reflectance at $485 \mathrm{~nm}$. The mean colour values of the longissimus dorsi, gluteus medius and gluteus profundus from the pigs on ad lib. feeding which received ration Am were generally darker than the corresponding muscles in the pigs on restricted feeding on the same ration. In pigs given ration $\mathrm{Br}$, however, the situation was reversed.

Long-chain fatty acid analysis. The backfat above the tenth rib was analysed for fatty acids by gas-liquid chromatography. With both rations the mean percentage of saturated fatty acids was significantly lower for the pigs on restricted feeding than for those on ad lib. feeding.

\section{DISCUSSION}

A similar pattern of results was obtained at Columbus and Shinfield when comparing American- and British-type rations for growing pigs despite the natural differences in environment and those between the Large White pigs used at Shinfield and the Yorkshire pigs used at Columbus. It was observed, however, that when feed was available $a d l i b$. the Large White pigs consumed daily more than the Yorkshires. Both breeds found the American- and British-type rations palatable, and under the same feeding conditions, restricted or $a d l i b$, the Large White pigs at Shinfield grew faster but did not convert their feed more efficiently than the Yorkshire pigs in Columbus given the same type of ration. At both centres and on both feeding regimes pigs receiving the American-type ration grew faster and utilized their feed more efficiently than pigs receiving the British-type ration, but their carcasses were considerably fatter. No doubt, these effects were due, at least in part, to the higher energy content of the American-type ration.

Although the experiment was not designed to compare the ad lib. and restricted methods of feeding (different management, group feeding in one instance and individual feeding in the other, and unrelated pigs were involved in such a comparison), it is of interest to note that, at both centres and on both rations, the pigs on ad lib. feeding 
grew faster than pigs given a restricted amount of feed. The differences in efficiency of feed conversion with the two methods of feeding were small and, except for the British-type ration in Columbus, in favour of the restricted feeding. Cold weather, which prevailed in Columbus during the final period of the test, may have contributed to this result as more pigs remained on this than on other treatments during this period. At both centres and on both rations the pigs on ad lib. feeding were considerably fatter than the pigs given restricted amounts.

The Large White carcasses were significantly longer than the Yorkshire carcasses, but length was not affected either by type of ration or method of feeding.

Only a summary is given here of the work on the composition and some of the characteristics of the meat from pigs at Columbus which received the two types of rations. A detailed description forms a part of a thesis prepared by one of the authors (Gundlach, 1964).

The availability of ingredients and their cost must be major considerations in assessing the practical value of rations for pigs. On the basis of prices of ingredients prevailing in Great Britain and in the United States at the time when the experimental rations were prepared, the cost per ton of the experimental rations was calculated to be:

$\begin{array}{lccccc} & \overbrace{\text { Ration no. I }} & \text { Ration no. } 2 & \overbrace{\text { Ration no. I }}^{\text {British costing }} & \text { Ration no. 2 } \\ \text { American-type ration } & £ 37 \cdot 2 & £ 36.5 & \$ 76.2 & \$ 74.1 \\ \text { British-type ration } & £ 32 \cdot 1 & £ 28.6 & & \$ 95.9 & \$ 85.6\end{array}$

These values are given for information as it is considered that economic appraisal of the two rations is beyond the scope of this report. It is, however, of general interest that at each centre the locally used rations were considerably cheaper than rations produced in accordance with a foreign formula.

\section{REFERENCES}

Buck, S. F., Harrington, G. \& Johnson, R. F. (rg62). Anim. Prod. 4, 25.

Gundlach, R. F. (1964). A study of certain chemical and physical factors of pork produced from American and British rations. Thesis, The Ohio State University. 